\title{
Faktor Ibu yang Mempengaruhi Persalinan Prematur di RSUD Arifin Achmad Pekanbaru
}

\author{
Risk Factors Incident Preterm Labor
}

\section{Liva Maita}

\section{Program Studi Magister Ilmu Kesehatan Masyarakat STIKes Hang Tuah Pekanbaru}

\begin{abstract}
Abstrak
Persalinan prematur atau Partus Prematurus adalah persalinan yang terjadi pada usia kehamilan kurang dari 37 minggu dihitung dari hari pertama haid terakhir. Data di RSUD Arifin Achmad Pekanbaru didapatkan data pada tahun 2010 didapatkan data jumlah persalinan sebanyak 2400 kasus, dengan persalinan prematur 190 kasus (7,91\%), tahun 2011 jumlah persalinan sebanyak 2287 kasus dengan persalinan prematur 279 kasus (12\%) dan pada periode Januari-April 2012 jumlah persalinan prematur 780 kasus (11,5\%). Tujuan penelitian adalah diketahuinya hubungan dari komplikasi kehamilan, riwayat persalinan prematur, anemia, umur dan paritas dengan persalinan prematur. Jenis penelitian yang digunakan adalah studi kasus kontrol. Populasi dalam penelitian ini adalah seluruh ibu bersalin di RSUD Arifin achmad Pekanbaru. Besarnya sampel terdiri dari 245 kasus dan 245 kontrol. Analisis data dilakukan secara univariat, bivariat dan multivariat dengan metode Regresi Logistic Ganda. Hasil penelitian adalah komplikasi kehamilan (95\% CI: 4,09-9,21), umur (CI 95\%: 1,58-3,69), dan paritas (95\% CI: 1,05-2,36) berhubungan dengan persalinan prematur. Kesimpulan yaitu variabel dominan yang berhubungan dengan kejadian persalinan prematur adalah komplikasi kehamilan dan tidak ada variabel counfounding. Saran kepada ibu hamil yang mengalami komplikasi kehamilan untuk memeriksakan kehamilan secara teratur minimal 4 kali selama kehamilan; pada ibu paritas tinggi disarankan menggunakan kontrasepsi mantap; dan Kepada tenaga kesehatan dapat mengelompokkan status pasien yang berisiko untuk mempermudah pemberian KIE.
\end{abstract}

Kata Kunci: Komplikasi kehamilan, umur ibu, paritas, Kejadian persalinan prematur

\section{Abstract}

Preterm labor or parturition Prematurus is labor that occurs at age less than 37 weeks of pregnancy is calculated from the first day of last period. Data in hospitals Arifin Achmad Pekanbaru data obtained in 2010 obtained data on the number of labor as much as 2400 cases, with 190 cases of preterm labor (7.91\%), in 2011 the number of births as 2287 cases with 279 cases of preterm labor (12\%) and in the period January-April 2012 Number 780 cases of preterm labor (11.5\%). The purpose of research is knowing the relationship of the complications of pregnancy, a history of preterm labor, anemia, age and parity with preterm labor. Type of research is a case-control study. The population in this study were all mothers giving birth at hospitals Arifin achmad Pekanbaru. Size of the sample consisted of 245 cases and 245 controls. Data analysis was performed by univariate, bivariate and multivariate Logistic Regression method Ganda. The results is a complication of pregnancy (95\% CI: 4.09 to 9.21), age (95\% CI: 1.58 to 3.69), and parity (95\% CI: 1.05 to 2.36) associated with preterm labor. The conclusion that the dominant variables associated with the incidence of preterm birth is a complication of pregnancy and no variable counfounding. Advice to pregnant women who experience pregnancy complications during their pregnancy on a regular basis at least four times during pregnancy and high parity mothers are advised to use contraception; To health professionals to classify the status of patients at risk to facilitate the provision of IEC.

Keywords: Complications of pregnancy, maternal age, parity, incidence of preterm labor

\section{PENDAHULUAN}

Persalinan prematur atau Partus Prematurus adalah persalinan yang terjadi pada usia kehamilan kurang dari 37 minggu dihitung dari hari pertama haid terakhir (Manuaba, 2007). Persalinan prematur yang terjadi sebelum usia kehamilan 34 minggu, menyebabkan tiga per empat dari keseluruhan kematian pada neonatus. Angka kematian bayi prematur dan sangat prematur yang terjadi pada usia gestasi kurang dari 32 minggu, dapat menyebabkan kematian sebesar 15 sampai dengan 75 kali lipat dibandingkan dengan bayi yang lahir aterm (Dirjen Bina Pelayanan Medik, 2010).

Angka kematian neonatal di Indonesia pada tahun 1991 sebesar 32/1000 Kelahiran Hidup, pada tahun 2007 sebesar 19/1000 kelahiran hidup, dan target Millenium Development Goals (MDGs) ke empat tahun 2015, angka kematian neonatus dapat diturunkan kembali (Kementerian Perencanaan Pembangunan Nasional, 2010). Adapun penyebab kematian adalah gangguan/ kelainan pernafasan (Respiratory Disorders) sebesar 35,9\% dan bayi prematur sebesar 
$32,4 \%$ (Badan penelitian dan pengembangan kesehatan, 2008). Data yang diperoleh dari Rekam Medik RSUD Arifin Achmad Pekanbaru didapatkan data tahun 2010 didapatkan data jumlah persalinan sebanyak 2400 kasus, dengan persalinan prematur 190 kasus $(7,91 \%)$, pada tahun 2011 jumlah persalinan sebanyak 2287 kasus dengan persalinan prematur 279 kasus (12\%) dan pada periode Januari-April 2012 jumlah persalinan prematur 780 kasus $(11,5 \%)$.

RSUD Arifin Achmad merupakan rumah sakit rujukan di provinsi Riau. Mengingat belum adanya penelitian mengenai faktor yang berhubungan dengan persalinan prematur berdasarkan umur, paritas, anemia, komplikasi langsung kehamilan, riwayat prematur di RSUD Arifin Achmad, maka peneliti tertarik untuk meneliti faktor-faktor yang berhubungan dengan kejadian persalinan prematur di RSUD Arifin Achmad Pekanbaru tahun 2010 - 2012.

\section{METODE}

Jenis desain penelitian yang digunakan adalah observasional, dengan jenis desain studi kasus kontrol (case control study). Lokasi penelitian ini dilakukan di RSUD Arifin Achmad Pekanbaru tahun 2010-2012. Subjek dalam penelitian ini adalah ibu bersalin prematur yang terdata tahun 2010-2012 sebanyak 245 dan ibu yang bersalinan aterm yang terdata tahun 2010-2012. Besarnya samplel penelitian ditentukan dengan memperhatikan Odds Ratio (OR) hasil beberapa penelitian terdahulu tentang beberapa faktor yang berhubungan dengan persalinan prematur dengan alfa $5 \%$ dan beta $10 \%$. Teknik pengambilan sampel dengan cara systematic random sampling dan pengumpulan data secara sekunder. Analisis data dilakukan secara multivariate dengan metode regresi logistic ganda.

\section{HASIL}

Hasil uji bivariat terhadap 5 variabel berhubungan dengan persalinan prematur adalah Komplikasi kehamilan, anemia, umur dan paritas.

ibu yang mengalami komplikasi kehamilan beresiko melahirkan prematur 6 kali dibandingkan ibu yang tidak mengalami komplikasi kehamilan. ibu yang mengalami riwayat persalinan prematur beresiko melahirkan prematur 2,5 kali dibandingkan ibu yang tidak memiliki riwayat persalinan prematur. ibu yang mengalami anemia beresiko melahirkan prematur 1,6 kali dibandingkan ibu yang tidak mengalami anemia. ibu yang termasuk kategori umur beresiko (umur $<20$ tahun dan umur $>35$ tahun) lebih beresiko mengalami persalinan prematur 2,7 kali dibandingkan ibu yang tidak termasuk kategori umur yang beresiko (umur 20 tahun sampai dengan umur 35 tahun). ibu yang memiliki paritas tinggi (Multipara dan
Grandemultipara) beresiko melahirkan prematur 1,6 kali dibandingkan ibu yang memiliki paritas rendah (Nullipara dan Primipara) (Lihat Tabel 1).

Hasil multivariat didapatkan variabel yang berhubungan bermakna dengan kejadian persalinan prematur yaitu komplikasi kehamilan, paritas dan umur. Odds Ratio (OR) dari variabel komplikasi kehamilan adalah 6,143 artinya ibu dengan komplikasi kehamilan lebih berisiko melahirkan persalinan prematur 6 kali lebih tinggi dibandingkan ibu yang tidak mengalami komplikasi kehamilan, setelah di kontrol variabel umur dan paritas.

Hasil analisis didapatkan Semakin besar nilai exp (B) berarti semakin besar pengaruhnya terhadap variabel dependen yang di analisis. Hal ini berarti komplikasi kehamilan paling besar pengaruhnya terhadap kejadian persalinan prematur. Tidak terdapat counfonding antara variabel. (Lihat Tabel 2)

\section{PEMBAHASAN}

\section{Komplikasi Kehamilan}

Menurut Rochjati (2003) yang menyatakan komplikasi kehamilan dapat menggangu kesehatan ibu dan pertumbuhan janin dalam kandungan sehingga meningkatkan resiko kelahiran bayi prematur. Dari hasil penelitian ini Komplikasi kehamilan yang terbesar disebabkan oleh Preeklamsi/eklamsi 68 kasus $(13,9 \%)$ dan Ketuban Pecah Dini (KPD) 55 kasus $(11,2 \%)$. Komplikasi preeklamsi/ eklamsia pada ibu hamil mempunyai pengaruh langsung terhadap kualitas janin karena terjadi penurunan darah ke plasenta yang mengakibatkan janin kekurangan nutrisi sehingga terjadi gangguan pertumbuhan janin dan terjadi nya peningkatan tonus otot rahim.

Agar ibu tidak mengalami komplikasi selama hamil dapat menyarankan ibu hamil memeriksakan kehamilan secara teratur minimal 4 kali selama kehamilan.

\section{Umur}

Umur reproduksi yang aman adalah umur 2035 tahun. umur yang dianggap berisiko adalah kurang 20 tahun dan lebih 35 tahun. Pada kehamilan di usia kurang dari 20 tahun rahim, panggul dan organ-organ reproduksi belum berfungsi dengan sempurna karena pada usia ini masih dalam proses pertumbuhan sehingga panggul dan dan rahim masih kecil. Selain itu, kekuatan otot-otot perineum dan otot-otot perut belum bekerja secara optimal. Sedangkan pada usia lebih dari 35 tahun berkaitan dengan kemunduran dan penurunan daya tahan tubuh. Pada usia lebih dari 35 tahun endometrium yang kurang subur memperbesar kemungkinan untuk menderita kelainan kongenital, sehingga berakibat terhadap kesehatan ibu maupun perkembangan janin yang berisiko untuk mengalami persalinan prematur (Widiyastuti, 2009). 
Dari hasil penelitian didapatkan persalinan prematur banyak terjadi pada ibu yang kurang 20 dan lebih 35 tahun. Hal ini sejalan dengan teori bahwa persalinan prematur lebih banyak terjadi pada ibu usia kurang 20 tahun dan lebih 35 tahun. pada ibu yang berusia lebih 35 tahun cenderung mengalami komplikasi dan masalah dalam kesehatan seperti hipertensi, DM, anemia, yang dapat meningkatkan kelahiran prematur. Sedangkan ibu yang umur kurang 20 tahun, terlalu muda untuk melahirkan sehingga secara fisik dan emosional belum matang.

Jika kehamilan terjadi pada umur $<20$ tahun, maka diperlukan konseling makanan bergizi pada ibu hamil untuk menghindari terjadinya anemia, dan jika kehamilan terjadi pada umur $>35$ tahun diperlukan pengawasan ketat oleh tenaga kesehatan melalui pengelompokkan status pasien yang berisiko untuk mempermudah dalam pemantauan, pencatatan dan pemberian KIE (Konseling, Informasi dan Edukasi).

\section{Paritas}

Pada penelitian ini ditemukan paritas tinggi (Multipara dan Grandemultipara) menyebabkan 1,6 kali terjadinya persalinan prematur. Menurut Saifuddin (2009) menyatakan bahwa wanita yang pernah melahirkan lebih dari satu kali atau yang termasuk dalam paritas tinggi (Multipara dan Grandemultipara) mempunyai resiko lebih tinggi mengalami persalinan prematur karena menurunnya fungsi alat reproduksi dan meningkat pula resiko terjadinya perdarahan antepartum. Paritas tinggi berkaitan erat dengan penmbahan usia ibu melahirkan.

Wanita yang termasuk paritas tinggi mempunyai risiko lebih tinggi mengalami persalinan prematur karena menurunnya fungsi alat reproduksi dan meningkatkan pula risiko terjadinya perdarahan antepartum yang dapat menyebabkan terminasi kehamilan lebih awal. Olehsebab itu, Ibu yang sudah memiliki anak 3 orang sebaiknya diberikan konseling $\mathrm{KB}$ dan menganjurkan ibu untuk menggunakan kontrasepsi mantap (MOW/MOP).

Tabel 1

Hasil Analisis Bivariat

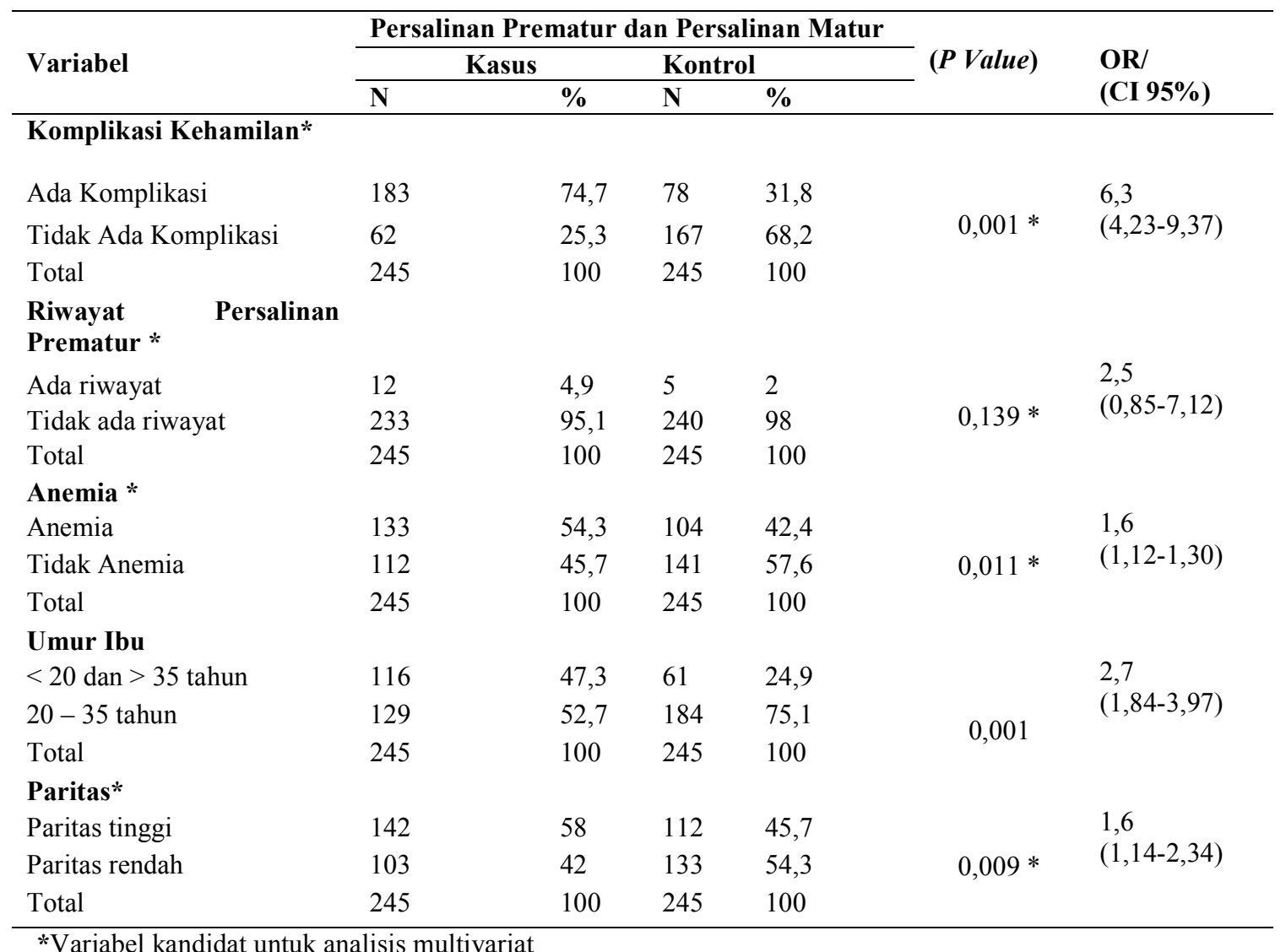

*Variabel kandidat untuk analisis multivariat 
Tabel 2

Pemodelan Multivariat Akhir

\begin{tabular}{lcccc}
\hline Variabel & $\begin{array}{c}P \\
\text { value }\end{array}$ & $\begin{array}{c}\text { Exp } \\
\text { (B) }\end{array}$ & \multicolumn{2}{c}{$\begin{array}{c}\text { 95\% CI. For EXP } \\
\text { (B) }\end{array}$} \\
\cline { 4 - 5 } & & & Lower & Upper \\
\hline Komplikasi & 0,000 & 6,143 & 4,097 & 9,213 \\
Kehamilan & & & & \\
Umur & 0,000 & 2,418 & 1,583 & 3,694 \\
Paritas & 0,027 & 1,577 & 1,053 & 2,362 \\
& & & & \\
\hline
\end{tabular}

\section{KESIMPULAN}

Faktor komplikasi kehamilan menyebabkan terjadinya kejadian persalinan prematur 6 kali dibandingkan yang tidak memiliki komplikasi kehamilan. Faktor Umur ibu $<20$ tahun dan $>35$ tahun menyebabkan terjadinya kejadian persalinan prematur 2,7 kali dibandingkan umur ibu 20-35 tahun. Faktor Paritas tinggi menyebabkan terjadinya kejadian persalinan prematur 1,6 kali dibandingkan yang paritas rendah. Tidak ada variabel confounding dari hasil penelitian. Variabel yang tidak berhubungan sebab akibat dengan kejadian persalinan prematur adalah riwayat prematur dan anemia.

\section{SARAN}

Diharapkan kepada ibu hamil yang mengalami komplikasi kehamilan untuk memeriksakan kehamilan secara teratur minimal 4 kali selama kehamilan; Kepada ibu paritas tinggi untuk dapat menggunakan kontrasepsi mantap; dan kepada tenaga kesehatan dapat melakukan pemantauan yang ketat pada ibu hamil melalui pengelompokkan status pasien yang berisiko untuk mempermudah dalam pemantauan, pencatatan dan pemberian KIE (Konseling, Informasi dan Edukasi).

\section{UCAPAN TERIMA KASIH}

Ucapan terima kasih ditujukan kepada Direktur RSUD Arifin achmad Pekanbaru, Kepala Ruangan Rekam Medis RSUD Arifin achmad, Kepala Ruangan Camar I RSUD Arifin achmad dan Ketua Prodi Pasca sarja Magister STIKes Hang Tuah Pekanbaru Prof. Dr.dr. Buchari Lapau, MPH ini, DR. dr. Toha Muhaimin, MSc dan dr. Sri Suryaningsih, MSc yang memberikan masukan pada penelitian.

\section{DAFTAR PUSTAKA}

Badan Penelitian Dan Pengembangan Kesehatan. (2008). Riset Kesehatan Dasar 2007 Dalam Laporan Nasional. Jakarta. Departemen Kesehatan RI

Dirjen Bina Pelayanan Medik RI. (2010). Hasil Kajian HTA Tentang Prediksi Persalinan Preterm. Disajikan Dalam Konvensi HTA 16 Juni 2010.

Kementerian Perencaan Pembangunan Nasional.(2010). Laporan Pencapaian Tujuan Pembangunan Millennium Di Indonesia 2010. Jakarta. Kementerian Perencaan Pembangunan Nasional

Laporan Rekam Medik RSUD Arifin Achmad Provinsi Riau Tahun 2009 s.d 2011

Manuaba, I. B. G. (2007) Pengantar Kuliah Obstetrik. Jakarta. EGC.

Rochjati, P. (2003) Skrining Antenatal Pada Ibu Hamil, Surabaya, Airlangga University Press.

Saifuddin, A. B. (2009) Buku Acuan Pelayanan Kesehatan Maternal Dan Neonatal. Jakarta, YBPSP.

Widiyastuti, Y. (2009). Kesehatan Reproduksi. Yogyakarta. Fitramaya. 